\title{
Analysing Sport Spectator Identification Levels of University Students with Their Favorite Team
}

\section{Cagrı Ilk}

Acıbadem Mehmet Ali Aydınlar University, Sports Sciences Faculty, Turkey

\section{Cemal Guler}

Istanbul University-Cerrahpasa/ Sports Sciences Faculty, Turkey

Doi:10.19044/ejes.v7no2a3 URL:http://dx.doi.org/10.19044/ejes.v7no2a3

\begin{abstract}
The aim of the study is to determine the sport spectator identification level of the sport students with the teams they support. A total of 225 students at Acibadem University, $74.7 \%$ women and $25.3 \%$ men, participated in the study voluntarily. The "Sport Spectator Identification Scale" developed by Wann and Branscombe (1993) was administered as the data collection instrument of the study. The validity and reliability study in Turkish was completed by Günay and Tiryaki (2003). The scale is in Likert-type which is scored between 1 and 8 and has a single dimension consisting of 7 items. Scores were represented as $1=$ not important, and $8=$ very important, in which high scores signified high identification levels. The internal consistency of the scale (Cronbach Alpha) was .93. Shapiro Wilk test was applied to identify the normal distribution of the data and a non-normal distribution was found. In the analysis of the data, Mann Whitney $U$ test was applied for gender, and Kruskal Wallis test was used for age, monthly income, class and teams they support. To the research results, while there was a significant difference in the identification level of university students with the teams they support, in terms of gender, class, teams and matches they follow, no meaningful difference was found for age and monthly income variables.
\end{abstract}

Keywords: Team identification, sport fans, university students.

\section{Introduction}

In a Latin root, sport word is derived from the word disporte which means separating from each other and scattering. In time, the word has transformed and gained its final form as sport (Talimciler, 2010). If sport is defined as physical activities based on institutionalized competition spirit, the components of institutionalization should be explained. The rules in sport are 
specified and shaped by official institutions rather than by the expressions of random individuals, personal interests, hobbies or certain instantaneous approaches (Tükenmez, 2011).

When and how sport began has always been a topic of discussion. Sport scientists divide ancient sportive activities into two categories as 'gamebased' and 'war-based' sport. In this sense, it is likely to say that the roots of sport date back to the period of the first runner, jumper or wrestler. Sport historians deal with sport as a work-based activity rather than a game, and consider spear-throwing as the first sportive activity in history (Çakır, 2017).

Sport can be defined as a process in which mankind combines skills and war methods against nature -with or without tools- and, it is used for playing and distracting from work, individually or collectively (Fişek, 1998). The first sports activity organizations in history can be seen in Ancient Greece. And, the first recorded Olympic Games were held in $776 \mathrm{BC}$ for Zeus (Durgun, 2007).

Sport is a platform that the entire world utilizes through gathering individuals from different social backgrounds and enabling billions of people to meet in the same environment (Donuk, 2016). It is possible to mention about numerous definitions of sport. When the common aspects of all the definitions are considered, sport is an activity or phenomenon that requires both physical power and skill, is performed on the basis of certain rules and ensures socializing. As the amount of leisure time today has increased, the motive to move has emerged. Sport is acknowledged as an indicator that affects all the aspects of social life and a sign of the welfare of the individuals (Yetim, 2000).

Sport fans are the individuals who support sports, athletes or teams and follow the games. Sport spectator represents the individuals who follow, listen and watch sport events and games (Wann, 1997). Sport spectators act based on winning or losing in a game. They have a high sense of belonging feeling for the team or sport player. Participation in sport takes place in two ways, as active and passive. Active participation refers to the direct involvement of individuals to a specific sport branch. However, passive participation stands for the case in which an individual takes the spectator role in a sport game. The researchers stated that being a sport spectator is a passive participation and equal to laziness, as it is not comparable to active participation (Jacobson, 2003). The popularization of sport and its practice by the larger audiences have also contributes the productions of various sport equipment. Specifically, the increasing number of spectators in professional competitions and the ticket prices have lead the sport industry to be an independent sector (Çakır, 2017).

Team identification concept can be explained with spectators' psychological attachment to a team. An individual becomes happy if the supported team wins, or vice versa (Güllü and Güçlü, 2006). In terms of social relationships, identification is the sense of integration or belonging to a certain 
team (Parker, 2007). Spectators see themselves as a part of their team. In recent years, individuals' psychological attachment to a team has drawn the attention of the sport scientists (Wann and Branscombe, 1993; Wann et al., 2001). Additionally, commitment to a team which is of great importance for sport marketers plays a direct or indirect role on sport consumption through participation to team events and purchasing products (Fisher, 1998; Kwonand Armstrong, 2006; Madrigal, 2000; Matsuoka et al., 2003; Theodorakis et al., 2009; Wakefield, 1995). The fans do their best to support their team by participating in group activities and acting in unison. These behaviors are thought to make sport spectator different from others. Thus, a higher number of sport spectators reinforce the strength of the team (Demirkan, 1991).

An identity acquisition or identification through participating in a group activity is of positive effects on the individual. Identification with society can result in such outcomes. The disappointed individuals can find the chance to change themselves by participating in a group (Hoffer, 2007). Within this context, this study aims to analyze the identification level of university students with their teams based on certain demographic variables

\section{Methods and Findings}

The study examines university students' identification levels with the sport teams they support. The study sample consisted of 168 female $(74.7 \%)$ and 57 male $(25.3 \%)$ students between 16-28 years old at the undergraduate level at Acibadem University. The Participants were selected and participated in the research on random and a voluntary basis. The data collection instruments were designated as Personal Information Form with gender, age, monthly income, class, the favorite team and watching game status variables and the Sport Spectator Identification Scale - SSIS which was developed by Wann and Branscombe (1993). The validity and reliability, and translation studies of the instrument were conducted by Güney and Tiryaki (2003). It is a Likert-type scale scored between 1 and 8 points, and consists of 1 dimension and 7 items. The scores are represented between 1 and $8-1=$ not important, I don't like it, 8= very important, I like it- and high scores signified high identification levels. IBM Statistics 25.0 package program was used in data analysis. The internal consistency of the instrument (Cronbach Alpha) was 93. Shapiro Wilk test was applied to determine the normal distribution of the data, and to the test results, a non-normal distribution was found. Hence, Mann-Whitney U and Kruskal Wallis tests were applied. 
Table 1 The distribution of the participants' personal information

\begin{tabular}{|c|c|c|c|}
\hline \multirow[t]{2}{*}{ Variables } & & $\mathbf{N}$ & $\%$ \\
\hline & Female & 168 & 74,7 \\
\hline \multirow[t]{3}{*}{ Gender } & Male & 57 & 25,3 \\
\hline & 16-18 year-olds & 57 & 25,3 \\
\hline & 19-21 year-olds & 133 & 59,1 \\
\hline \multirow[t]{5}{*}{ Age } & 22-24 year-olds & 19 & 8,4 \\
\hline & 25-27 year-olds & 6 & 2,7 \\
\hline & $\begin{array}{l}28 \text { years and- } \\
\text { older }\end{array}$ & 10 & 4,4 \\
\hline & $0-500 \mathrm{TL}$ & 84 & 37,3 \\
\hline & 501-1000 TL & 76 & 33,8 \\
\hline \multirow[t]{5}{*}{ Monthly Income } & $1001-1500 \mathrm{TL}$ & 36 & 16,0 \\
\hline & 1501-2000 TL & 9 & 4,0 \\
\hline & $\begin{array}{l}2001 \text { TL and } \\
\text { more }\end{array}$ & 20 & 8,9 \\
\hline & $1^{\text {st }}$ Grade & 132 & 58,7 \\
\hline & $2^{\text {nd }}$ Grade & 79 & 35,1 \\
\hline \multirow[t]{4}{*}{ Grades } & $3^{\text {rd }}$ Grade & 9 & 4,0 \\
\hline & $4^{\text {th }}$ Grade & 5 & 2,2 \\
\hline & Beşiktaş & 39 & 17,3 \\
\hline & Fenerbahce & 88 & 39,1 \\
\hline \multirow[t]{6}{*}{ The Supported Team } & Galatasaray & 82 & 36,4 \\
\hline & Trabzonspor & 4 & 1,8 \\
\hline & Other & 12 & 5,3 \\
\hline & Follow & 54 & 24,0 \\
\hline & Regularly & & \\
\hline & Follow & 99 & 44,0 \\
\hline \multirow{3}{*}{$\begin{array}{l}\text { Following } \\
\text { Matches }\end{array}$} & Sometimes & & \\
\hline & Do not Follow & 72 & 32,0 \\
\hline & Total & 225 & 100 \\
\hline
\end{tabular}

Table 1 presents the statistical findings related to the personal information of the participants. According to the analysis, it was concluded that $74.7 \%$ were "Female", $59.1 \%$ were between "19-21 year-olds", $37.3 \%$ had "0-500TL" monthly income, 93.3\% attended to a "Private" university, $58.7 \%$ were " 1 st grade" students, $36.4 \%$ were "Galatasaray" fans and, $44.0 \%$ "Sometimes" followed the games. 
Table 2 The distribution of participants' identification level

\begin{tabular}{lccccl}
\hline Scale & Mean & Sd & Min. & Max. & N \\
SSIS Total Scores & 30.90 & 14.72 & 7.00 & 56.00 & 225 \\
\hline
\end{tabular}

Table 2 shows the total scores of "Sport Spectator Identification Scale". The study included 225 participants in which the minimum score was "7" and the maximum score was " 56 ".

Table 3 The score distribution for the gender variable

\begin{tabular}{llllll}
\hline Scale & Gender & $\mathbf{N}$ & $\begin{array}{l}\text { Mean } \\
\text { Rank }\end{array}$ & U & P \\
& Female & 168 & 153.11 & \\
SSIS & Male & 57 & 99.39 & 2502.000 & $\mathbf{. 0 0 0}^{*}$ \\
\hline \multicolumn{6}{c}{$* p<0.05$}
\end{tabular}

The results of "Mann-Whitney U" test that was administered to reveal whether sport spectators possesed different identification levels for the gender variable are shown in Table 3. According to test results, there were meaningful differences in identification levels for gender variable, which indicated that female participants had higher mean rank scores than the male participants.

Table 4 The score distribution for the age variable

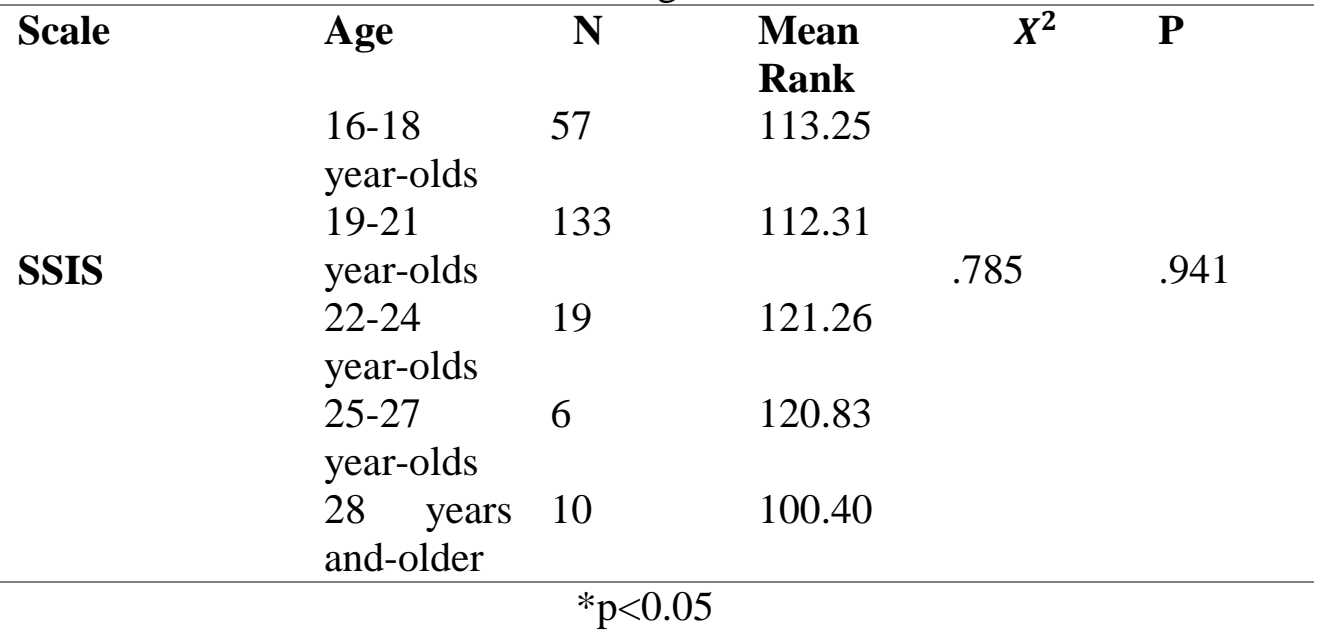

As seen in Table 4, the "Kruskal Wallis" test was applied to see if sport spectators had different identification levels for the age variable. Considering the test results, there were no significant differences in identification levels for age variable. However, identification levels of the participants between 22-24 years old were higher than the participants in other age ranges. 
Table 5 The score distribution for monthly income variable

\begin{tabular}{|c|c|c|c|c|c|}
\hline \multirow[t]{5}{*}{ Scale } & Monthly & $\mathbf{N}$ & Mean & $X^{2}$ & $\mathbf{P}$ \\
\hline & Income & & Rank & & \\
\hline & $0-500 \mathrm{TL}$ & 84 & 105.82 & & \\
\hline & $501-1000$ & 76 & 109.05 & & \\
\hline & TL & & & & \\
\hline \multirow[t]{5}{*}{ SSIS } & $1001-1500$ & 36 & 127.39 & \multirow[t]{5}{*}{8.105} & \multirow[t]{5}{*}{.088} \\
\hline & TL & & & & \\
\hline & $1501-2000$ & 9 & 91.06 & & \\
\hline & & & & & \\
\hline & $\begin{array}{l}2001 \mathrm{TL} \\
\text { and more }\end{array}$ & 20 & 142.15 & & \\
\hline
\end{tabular}

Table 5 shows the "Mann-Whitney U" test results which were conducted to determine if sport spectators showed different identification levels in monthly income variable. According to test results, there were no significant differences in identification levels for monthly income variable. However, the participants with 2001TL or more monthly income had higher identification level than the ones with other monthly income ranges.

Table 6 The score distribution for class variable

\begin{tabular}{lllllll}
\hline Scale & Class & $\mathbf{N}$ & $\begin{array}{l}\text { Mean } \\
\text { Rank }\end{array}$ & $\boldsymbol{X}^{\mathbf{2}}$ & $\mathbf{P}$ & \\
& & & 105.98 & & \\
& $1^{\text {st }}$ class & 132 & 122.39 & & \\
SSIS & $2^{\text {nd }}$ class & 79 & 155.22 & 8.773 & $\mathbf{. 0 3 2}^{*}$ \\
& $3^{\text {rd }}$ class & 9 & 74.00 & & \\
\hline & $4^{\text {th }}$ class & 5 & & &
\end{tabular}

Table 6 shows the "Kruskal Wallis" test results which were done to find out whether sport spectators had different identification levels for the class variable. According to test results, there were significant differences in identification levels for the class variable. Identification levels of participants in $3^{\text {rd }}$ grade were higher than other participants. 
Table 7 The score distribution for the supported team variable

\begin{tabular}{llllll}
\hline Scale & Team & $\mathbf{N}$ & $\begin{array}{l}\text { Mean } \\
\text { Rank }\end{array}$ & $\boldsymbol{X}^{\mathbf{2}}$ & $\mathbf{P}$ \\
& Beşiktaş & 39 & 118.27 & & \\
& Fenerbahçe & 88 & 118.22 & & \\
\multirow{2}{*}{ SSIS } & Galatasaray & 82 & 116.93 & & \\
& Trabzonspor & 4 & 121.75 & 21.760 & $\mathbf{. 0 0 0}^{*}$ \\
& Other & 12 & 27.83 & & \\
\hline & & $* \mathrm{p}<0.05$ & & &
\end{tabular}

Table 7 presents the "Kruskal Wallis" test results administered to determine whether sport spectators were of different identification levels for the favorite team variable. To the test results, there were significant differences between identification levels for the favorite team variable. Trabzonspor supporters' identification levels were higher than other supporters.

Table 8 The score distribution for the following status variable

\begin{tabular}{llllcl}
\hline Scale & $\begin{array}{l}\text { Following } \\
\text { status }\end{array}$ & $\mathbf{N}$ & $\begin{array}{l}\text { Mean } \\
\text { Rank }\end{array}$ & $\boldsymbol{X}^{\mathbf{2}}$ & $\mathbf{P}$ \\
& $\begin{array}{l}\text { Regularly } \\
\text { SSIS }\end{array}$ & 54 & 190.41 & & \\
& $\begin{array}{l}\text { Sometimes } \\
\text { Don't }\end{array}$ & 99 & 114.73 & 138.667 & $\mathbf{. 0 0 0 *}$ \\
& follow & & 52.56 & & \\
\hline & & & & \\
& & & & \\
& & & & & \\
\end{tabular}

In Table 8, the "Kruskal Wallis" test results conducted to determine whether sport spectators had different identification levels for the following status variable were presented. And to the test results, there were significant differences in identification levels for the following status variable. Participants who regularly followed their teams had higher identification level than the participants in the other groups.

\section{Conclusion}

Sport is defined as an activity for entertainment, healthy life and interaction with other people. It has become a field that gathers different age groups and cultures without any discrimination. It is a powerful instrument to create an influential connection among the individuals who live in different geographical regions, and people support the teams of the countries they do not know (Akkaya, 2016). 
Pehlivan (2004) expressed that sport has become a phenomenon that integrates peace, rights, laws, compassion, discipline, happiness and love concepts. Sport enables individuals to represent their countries in equal and fair way without language, religion and color discrimination. Over the years, individuals' commitment to their favorite sport clubs has consolidated and their identification levels have begun to increase. Those fans show their commitment by purchasing the licensed products of the club, going to games or supporting it on social media. Being a fan is a sense of belonging and regarded as being a part of a group in which one's thoughts are supported by other group members (Dever, 2013). Sport fans are described as the public mass that offers material or immaterial support for the club activities, purchases service and products provided by the clubs and supports their team domestically and internationally under any circumstances (Kirdar, 2006).

Today, identification concept has become a critical parameter that specifies fans' attachment to their team. As a committed member of a society, identification refers to acting and behaving on the basis of society (Acet, 2005). The connection among the fans and the team presents identification concepts. Funk and James (2001) clarified this concept as an individual's association with team members and having a social and psychological relationship. Team identification levels are essential for the clubs. High identification levels among the spectators are predicted to enhance both material and immaterial strength of the clubs. Within the scope of the purpose of this study, university students' identification levels were investigated, which is crucial for all sport branches.

When the study results were analyzed, it was found that there were significant differences in identification levels for gender variable ( $>0.05)$. The scores of female spectators were higher than the scores of male spectators. Based on this result and the frequent use of social media in today's world is considered, it can be inferred that female spectators can show their commitment to team on social media platforms without going to the stadium. However, in "Identification Level of Sport Fans with Their Teams at Different Universities" paper written by Demirel et al. (2007), a higher identification level among male participants were revealed compared to female participants. Similarly, “An Analysis of High-School Student Fans' Identification Level with Their Favourite Team" study which was conducted by Altınok et al. (2017) indicated higher identification score averages for male fans compared to female fans. However, the results in the literature are not comparable to the results of this study.

To the study results, there were no significant differences in identification levels for the age variable $(p>0.05)$. However, the scores of 2224 year-old participants were higher than the scores of the ones in other age groups. In "A Study to Determine the Effects of Sport Club Brand Identity with 
Team Identification" research which was completed by Baran and Taşkın (2017), it was found that there was no significant difference between identification levels of Faculty of Economics and Administrative Sciences students, which is accordance with the current study results.

This study found no statistically meaningful difference in sport fans' identification levels for monthly income variable. However, the participants with 2001TL or higher monthly income scored higher than the ones with other monthly income ranges. High scores of the participants with high income might suggest that those participants have a higher chance to support their team financially than the low-income participants. The study on "a Logistic Regression Analysis to Identify the Factors on Purchasing Team Uniform with Sponsor Brand" administered by Tokmak and Aksoy (2016) revealed that an increase in one's monthly income results in spending much money on product sales to support the club, which in turn reinforces the identification with the team.

This study found a significant difference in sport fan identification levels for the class variable. The identification scores of the participants in $3^{\text {rd }}$ grade were higher than the scores of other participants in other grades. It can be inferred that as the participants were in higher grade levels in their education life, they learned more about their teams, spent more time in university social groups and attended to a team's fan club.

According to the study results related to the teams, significant differences were seen in identification levels for team variable. In this sense, Trabzonspor supporters' identification levels were higher than other team supporters. In a research by Ayhan et al. (2017), " Motivations to Buy Licensed Products: A Study on University Students", Trabzonspor team fans were found to possess higher identification levels. These results are in line with our study.

In this study, when the following status variable was analyzed, a significant difference was identified among sport fans. The participants who regularly followed their teams had higher identification level than the ones in the other groups. Thus, it can be stated that the more often fans follow their teams, the higher identification levels they will display. Fans' sense of belonging will increase as they follow their team and they begin to see themselves as a part of the team. In "An Analysis of Psychological Attachment of Football Fans to Their Team (Adlyaman City Sample)" by Kartal and Inan (2018), it was found that fans that followed their team via media had a stronger attachment, which is a supportive outcome for the current study results. Likewise, in "Analyses on Anger and Violence Behavior of Derby Game Spectators in Turkish Football Super League” by Dal et al. (2012) it was suggested that fans become sad when their team loses. Indeed, it is likely to say that those fans' team attachment is negatively affected in case of a failure. 
Ultimately, it was concluded that there was a meaningful difference in university students' team identification levels in terms of gender, class, favorite team and following status variables. It was revealed that the female participants, the students in the $3^{\text {rd }}$ grade and the fans who regularly follow their teams had higher identification scores.

This study was conducted with the students at Acıbadem University in Istanbul. In the future, students from different universities might be included to compare the results. Additionally, the study can be designed to become a more comprehensive research by analyzing individuals who are a member of a club.

\section{References:}

1. Acet M. (2005). Sporda Saldırganlık ve Şiddet, Istanbul: Morpa Kültür Publishing.

2. Akkaya O. (2016). Sosyal Medya ve Spor Pazarlaması İlişkisi Taraftar Tutumlarını Belirlemeye Yönelik Bir Araştırma Beşiktaş Spor Kulübü Örneği. Master Thesis, Selcuk University, Konya.

3. Altınok, B., Emir Ekinci N., Cimen, K., Özdilek Ç., Kaya İ. (2017) Lise Öğrencilerinin Taraftarı Oldukları Takım İle Özdeşleşme Düzeylerinin İncelenmesi, Sports Education Magazine, Cilt 1, Say1 1, 59-68

4. Ayhan B., Aktas H., Celik F. (2017). Lisansl1 Taraftar Ürünlerinin Kullanım Motivasyonları: Üniversite Öğrencileri Üzerine Bir Araştırma, Gümüshane University Electronic Journal of Communication Faculty, Volume (5). Number (2), September

5. Baran A., Taskin E. (2017) Spor Kulübünün Marka Kişiliğinin Takımla Özdeşleşme Üzerindeki Etkisini Belirlemeye Yönelik Bir Çalışma, Dumlupınar University, Journal of Social Sciences, Number 52 / April 2017

6. Cakır V.O. (2017). Sporun Sosyolojik Temelleri, Sports Publishing and Bookstore, Ankara, s.13

7. Çakır, V.O. (2017). Spor Sosyolojisi, Sports Publishing and Bookstore, Ankara, s.16

8. Dal S., Odabas İ., Suna N., Bulgan C. Ve Akkaya S. (2012). Türkiye Futbol Süper Ligi Derbi Maçı İzleyicilerinin Öfke ve Saldırganlık Davranışlarının İncelenmesi, Istanbul University Journal of Sports Sciences, Volume 4, Year 2012-2014

9. Demirel, M., Güven Karahan, B., Ünlü, H. (2007) Farklı Üniversitelerdeki Spor Taraftarlarının Takımları ile Özdeşleşme Düzeyleri, Nigde University Journal of Physical Education and Sports Sciences, Volume 1, Number 2, 76-86. 
10. Dever A. (2013). Endüstriyel Futbol ve Taraftarlık: Kayseri İli Örneği, Doctor's Thesis, Cumhuriyet University, Sivas.

11. Donuk B. (2016). Spor Yönetim Sanatı. S: 113. Istanbul. Ötüken Neşriyat A.Ş.

12. Durgun, D. (2007). Türkiye'de Sporun Gelişimi ve Değişen Kullanıcı Gereksinimlerini Karşılayıcı Yönde Modern Stadyum Yapılarının Temel Planlama Özellikleri. Trakya University Institute of Science and Architecture Department.

13. Fisher, R.J. (1998) 'Group-derivedconsumption: the role of similarityandattractiveness in identificationwith a favoritesportteam', Advances in Consumer Research, Vol. 25, No. 3, pp.283 288.

14. Fisek, K. (1998). Devlet Politikası ve Toplumsal Yapıyla İlişkileri Açısından Dünya'da ve Türkiye'de Spor Yönetimi. Ankara: Bagırgan Publishing.

15. Funk DC, James J. (2001). Thepsychologicalcontinuum model: A conceptualframeworkforunderstanding

an individual'spsychologicalconnection to sport. Sport Management Review, 4(2), 119-150.

16. Gustave L B, Çev. S. Demirkan, "Kitleler Psikolojisi”". s.153-154, Istanbul: Yagmur Publishing, 1991.

17. HofferErich. (2007). Kesin İnançlılar, Çev: ErkılGünur, İM Yayın Tasarım, s. 41, 101, 135

18. Güllü, M., Güclü, M. (2006) Ortaöğretim Öğrencilerinin Taraftarı Oldukları Spor Takımları İle Özdeşleşmelerinin İncelenmesi. 9th International Congress of Sports Sciences Proceedings Book. 3- 5 November, Mugla, s.686 - 689.

19. Jacobson, B. The Social Psychology of TheCreation of A Sport Fan Identity: A TheoreticalReview Of The Literature, Athletic Insight The Online Journal Of Psychology, Volume 5, Issue 2-June, 2003.

20. Kartal M. Ve İnan H. (2018) Futbol Taraftarlarının Takıma Psikolojik Bağlılık Düzeylerinin İncelenmesi (Adıyaman İli Örneği), Journal of Institute of Economic development and Social Researches, ISSN:2630-6166, Vol:4 / Issue:14, p.730-735

21. Kirdar, Y. (2006), Kurumsallaşan Spor Kulüplerinde Pazarlama İletişimi Faaliyetlerinin Spor Pazarlaması Sürecinde Kurum İmajı Üzerine Etkisi; Fenerbahçe Spor Kulübünde Bir Uygulama Örneği, Ege University Social Sciences Institute Unreleased Doctor's Thesis, Izmir.

22. Kwon, H.H. and Armstrong, K.L. (2006) 'Impulsepurchases of sportteamlicensemerchandise: whatmatters?', Journal of Sport Management, Vol. 20, No. 1, pp.101-119. 
23. Madrigal, R. (2000) 'Theinfluence of socialallianceswithsportteams on intentions to purchasecorporatesponsors' products', Journal of Advertising, Vol. 29, No. 4, pp.1-13.

24. Matsuoka, H., Chelladurai, P. and Harada, M. (2003) 'Direct andindirecteffects of teamidentificationandsatisfaction on intention to attendgames', Sport Marketing Quarterly, Vol. 12, No. 3, pp.244-253.

25. Parker, H. M. (2007). TheEffect of Negative Sponsor Information and Team Response on Identification Levelsand Consumer Attitudes. (Doktora tezi). Access address (https://etd.ohiolink.edu/!etd.send_file?accession=osu1180025349\&d isposition=inline

26. Pehlivan Z. (2004). Fair Play kavramının geliştirilmesinde okul sporunun önemi ve yeri. Journal of Spormeter Physical Education and Sports Sciences, 2(2), 49-53

27. Talimciler A. Sporun Sosyolojisi Sosyolojinin Sporu. Istanbul. Baglam Publishing 2010.

28. Theodorakis, N. D., Koustelios, A., Robinson, L. and Barlas, A. (2009) 'Moderating role of team identification on the relationship between service quality and repurchase intentions among spectators at professional sport', Managing Service Quality, Vol. 19, No. 4, pp.456473.

29. Tokmak G., Aksoy G. (2016). Futbol Taraftarlarının Takımın Forma Spornsor Markasına Olan Satın Alma Niyetlerini Etkileyen Faktörlerin Lojistik Regresyon Analizi ile Tespit Edilmesi, IU Journal of Sports Sciences 2016, (Vol) 6, (No) 2 1303-1414

30. Tükenmez M. (2011). Toplumbilim ve Spor, Kaynak Publishing, Istanbul. s.33

31. Wakefield, K.L. (1995) 'The pervasive effects of social influence on sporting event attendance', Journal of Sport\&SocialIssues, Vol. 19, No. 4, pp.335-351.

32. Wann, D. L. (1997) SportPsychology. New Jersey: Prentice-Hall. pp. 325-367.

33. Wann, D.L. and Branscombe, N.R. (1993) 'Sport fans: measuring degree of identification with the team', International Journal of SportPsychology, Vol. 24, No. 1, pp.1-17.

34. Wann, D.L. Melnick, M.J., Russell, G.W. and Pease, D.G. (2001) SportFans: The Psychology and Social Impact of Spectators, RoutledgePress, New York.

35. Yetim, A. (2000). Sosyoloji ve Spor. Topkar Typography: Trabzon, s.1. 